\title{
PRODUCTION AND INFECTIVITY OF INOCULUM OF ARBUSCULAR MYCORRHIZAL FUNGI MULTIPLIED IN A SUBSTRATE SUPPLEMENTED WITH TRIS-HCL BUFFER
}

\author{
Fábio Sérgio Barbosa da Silva ${ }^{1}$; Adriana Mayumi Yano-Melo²; Leonor Costa Maia ${ }^{3 *}$ \\ ${ }^{1}$ Universidade de Pernambuco, Petrolina, PE, Brasil; ${ }^{2}$ Universidade Federal do Vale do São Francisco, Petrolina, PE, Brasil; \\ ${ }^{3}$ Universidade Federal de Pernambuco, Centro de Ciências Biológicas, Departamento de Micologia, Recife, PE, Brasil
}

Submitted: February 24, 2007; Returned to authors for corrections: November 01, 2007; Approved: November 15, 2007.

\begin{abstract}
The effect of adding Tris- $\mathrm{HCl}$ buffer on production and infectivity of AMF inoculum was investigated. Sporulation of Glomus etunicatum, Acaulospora longula and Gigaspora albida was improved in solution with buffer. The infectivity of G. etunicatum increased after storage, what suggests that the inoculum of this isolate is benefited by storage.
\end{abstract}

Key words: mycorrhiza, organic buffer, sporulation, storage

Due to the obligate biotrophism, the production of inoculum is one of the obstacles for application of arbuscular mycorrhizal fungi (AMF) to benefit plant crops of economic importance. Among the methods for inoculum production, one is cultivation in sand and vermiculite, supplemented with nutrient solutions containing organic buffers in its formulation; this allows high production of spores (13).

Organic buffers have the property of minimizing the alterations of the $\mathrm{H}^{+}$ion concentration and are used for maintaining the $\mathrm{pH}$ of the AMF growth media (14). The effect of a buffer on growth of AMF depends on its constitution (14) and concentration in the culture medium (12). Researches related with use of organic buffers for maintenance of $\mathrm{pH}$ and for stimulating mycelial growth are restricted to a few species of AMF, mostly Glomus $(3,14)$.

The AMF inoculum should be produced in high density, and maintain the infectivity and effectivity for a long period of time. Although not much information regarding storage of AMF is available (20), the maintenance of the inoculum in the conditions under which it was produced is recommended (7). It has also been mentioned that maintenance of AMF inoculum at low temperature stimulates germination and spore development $(22,24)$; however, the ideal temperature for storage of each AMF isolate should be determined.
In this work the most suitable concentration of Tris- $\mathrm{HCl}$ buffer for production of spores of AMF and for maintenance of the infectivity of the inoculum, under different temperatures, was investigated.

Experiment 1. Effect of addition of Tris-HCl buffer on sporulation of AMF. Seeds of Panicum miliaceum L. (50 per pot) were disinfected with Sodium Hypochlorite $(0.05 \% / 10 \mathrm{~min})$ and washed with distilled water before being planted. The substrate used was washed river sand $\left(\mathrm{pH}_{\mathrm{H} 2 \mathrm{O}} 7.1\right)$ and vermiculite of medium granulation $(1: 1 \mathrm{v} / \mathrm{v})$. Both were autoclaved $\left(30 \mathrm{~min} . / 1 \mathrm{~atm} / 120^{\circ} \mathrm{C}\right)$, in two consecutive days, and used 15 days after sterilized. Spores of Glomus etunicatum Becker and Gerd. (UFPE 06), Gigaspora albida Schenck and Smith (UFPE 01), Scutellospora heterogama (Nicol. and Gerd.) Walker and Sanders (UFPE 19) and Acaulospora longula Spain and Schenck (UFPE 21) were inoculated as suspensions (50 spores of each AMF), in plastic pots $(400 \mathrm{~mL})$ with $300 \mathrm{~g}$ of substrate, below the host seeds. The pots were maintained in a greenhouse for 85 days; temperature $\left(\mathrm{T}_{\min } 22.81^{\circ} \mathrm{C} ; \mathrm{T}_{\max } 32.39^{\circ} \mathrm{C}\right)$, humidity $\left(\mathrm{RU}_{\text {min. }}\right.$ 45.62\%; $\left.\mathrm{RU}_{\max .} 81.13 \%\right)$ and light were not controlled. The pots were irrigated every other day with nutrient solution [Hoagland and Arnon 1950 modified by Jarstfer and Sylvia (8)] supplied with $0,10,25,50$ or $75 \mathrm{mM}$ of Tris - HCl buffer (pH 6.5). The experiment was evaluated 85 days after the inoculation.

*Corresponding Author. Mailing address: Universidade Federal de Pernambuco, Centro de Ciências Biológicas, Departamento de Micologia, 50670420, Recife, PE, Brasil. E-mail: leonorcmaia@yahoo.com.br 
The AMF spores were extracted from the soil by wet sieving (4) and sucrose centrifugation (9), placed on Petri dishes and quantified using a stereomicroscope. The experimental design was entirely at random in a factorial arrangement of: 4 species of AMF x 5 concentrations of Tris- $\mathrm{HCl}$ buffer, with 5 replicates (100 experimental units).

Experiment 2. Evaluation of the infectivity of the AMF inoculum produced in a substrate irrigated with nutrient solution supplemented with Tris-HCl buffer. The infectivity potential of the inocula produced in the first experiment was evaluated by the MIP method - mean percentage of infection (7). The inocula that produced higher density of spores per gram of substrate in the previous experiment were chosen for this assay (inoculum of G. albida, A. longula and G. etunicatum produced in the treatments supplied respectively with $75 \mathrm{mM}, 50 \mathrm{mM}$ and 10 $\mathrm{mM}$ of Tris- $\mathrm{HCl}$ buffer). The inoculum was constituted of spores, hypha and colonized roots. The infectivity of each inoculum was estimated before and after storage for 120 days, at $28^{\circ} \mathrm{C}$ (room temperature) and at $4^{\circ} \mathrm{C}$ (refrigerator). Samples of the material produced in the first experiment were diluted ( $1: 10$ $\mathrm{v} / \mathrm{v}$ ) in sand, using corn (Zea mays L. cv Assum preto) as the host plant. After 30 days, roots were clarified and stained with Trypan blue $(0.05 \%)$ in lactoglycerol (15); the percentage of colonization was estimated by the intersect method (5). For each AMF the experimental design was completely at random with 3 treatments of storage and 7 replicates $(=21$ experimental units). The pots were maintained in a greenhouse for 30 days after seedling emergence. The inoculum was considered viable, from the commercial point of view, when roots of the host presented at least $25 \%$ of mycorrhizal colonization (7).

For both experiments the data were transformed $(\sqrt{ } \mathrm{x}+0.5)$ for variance analysis and the means compared by Tukey (for sporulation) and LSD at 5\% probability (for infectivity), using the Statistica Program (19).

Different responses on sporulation of the AMF were found in relation to buffer concentrations (Table 1), except for $S$. heterogama. The incorporation of $>10 \mathrm{mM}$ of Tris- $\mathrm{HCl}$ to the substrate favored the sporulation of G. etunicatum. Gigaspora albida presented significant increase on sporulation when the substrate received concentrations higher than $25 \mathrm{mM}$ of buffer. Maximum production of spores of $A$. longula was obtained in substrate receiving concentrations $\geq 50 \mathrm{mM}$ of buffer.

The sporulation of G. etunicatum increased in all treatments with Tris- $\mathrm{HCl}$ comparing with the control (without buffer). Differently from the observed with A. longula, sporulation of $G$. albida was positively correlated with the increase of buffer concentrations in the nutrient solution $(\mathrm{P}<0.05 ; \mathrm{r}=0.90)$. Higher production of spores was attained by G. etunicatum, differing from those reached by the other species in all treatments, with and without buffer. Conversely, S. heterogama did not multiply well, in comparison with the other fungi, independently of presence of buffer in the growth medium.

The storage at $4^{\circ} \mathrm{C}$ preserved the infective potential of the $\mathrm{AMF}$ inocula in relation to the treatment maintained at $28^{\circ} \mathrm{C}$ (Table 2). With the exception of G. albida, the preservation of the others AMF under environmental conditions significantly reduced the infectivity of the inoculants. The infective potential of $G$. etunicatum increased when the inoculum was stored at $4^{\circ} \mathrm{C}$, while that of $\mathrm{G}$. albida was not affected by the storage treatments.

The addition of Tris- $\mathrm{HCl}$, in any concentration, promoted high sporulation of G. etunicatum. The benefit of adding low concentrations of buffers in the medium, for sporulation of AMF was mentioned for some Glomus species. Douds Jr. (3) observed that $10 \mathrm{mM}$ of Tris favored the germination and the mycelial growth of Glomus mosseae.

Species of Gigaspora form a high amount of soil biomass, when compared to other AMF (6). This may result in high amounts of $\mathrm{CO}_{2}$ (from respiration); the reaction of $\mathrm{CO}_{2}$ with water reduced the $\mathrm{pH}$ of the rhizosphere (21). This could justify the efficiency of the buffer in higher concentrations, once that it would be needed high amounts of the buffer to make the $\mathrm{pH}$ stable. Conversely, G. etunicatum develops hypha that are thinner than those of $G$. albida, presenting lower respiration values; thus, the $10 \mathrm{mM}$ concentration would be enough to stabilize the alterations on $\left[\mathrm{H}^{+}\right]$.

Table 1. Production of spores ( $\mathrm{g}^{-1}$ substrate) of Acaulospora longula, Gigaspora albida, Glomus etunicatum and Scutellospora heterogama after 85 days associated with Panicum miliaceum, irrigated with nutrient solution [Hoagland and Arnon, 1950, modified by Jarstfer and Sylvia, 1992] and supplemented with Tris-HCl buffer.

\begin{tabular}{lrrrrr}
\hline \multirow{2}{*}{ AMF } & \multicolumn{5}{c}{ Concentrations de Tris- $\mathrm{HCl}(\mathrm{mM})$} \\
\cline { 2 - 6 } & \multicolumn{1}{c}{0} & 10 & \multicolumn{1}{c}{25} & 50 & 75 \\
\hline A. longula & $11.72 \mathrm{bB}$ & $17.53 \mathrm{bB}$ & $14.23 \mathrm{cB}$ & $43.80 \mathrm{bA}$ & $35.00 \mathrm{bcAB}$ \\
G. albida & $33.09 \mathrm{bC}$ & $42.30 \mathrm{bBC}$ & $56.34 \mathrm{bAB}$ & $53.56 \mathrm{bAB}$ & $65.10 \mathrm{bA}$ \\
G. etunicatum & $104.73 \mathrm{aB}$ & $161.28 \mathrm{aA}$ & $198.44 \mathrm{aA}$ & $175.69 \mathrm{aA}$ & $292.01 \mathrm{aA}$ \\
S. heterogama & $4.62 \mathrm{bA}$ & $9.94 \mathrm{bA}$ & $10.80 \mathrm{cA}$ & $14.37 \mathrm{cA}$ & $15.05 \mathrm{cA}$ \\
\hline
\end{tabular}

Means followed by the same small letter (column) and capital letter (line) do not differ by Tukey $(\mathrm{P}<0.05)$. 
Table 2. Infectivity (\%) of the inocula of AMF produced in a sand vermiculite substrate irrigated with Hoagland and Arnon nutrient solution modified by Jarstfer and Sylvia (1992) and supplemented with Tris- $\mathrm{HCl}$ buffer, calculated at time 0 (before storage) and after maintenance for 120 days at $4^{\circ} \mathrm{C}$ and at room temperature $\left(28^{\circ} \mathrm{C}\right)$.

\begin{tabular}{cccc}
\hline \multirow{4}{*}{ Treatments } & \multicolumn{3}{c}{ Inocula } \\
\cline { 2 - 4 } & $\begin{array}{c}\text { Gigaspora } \\
\text { albida }\end{array}$ & $\begin{array}{c}\text { Acaulospora } \\
\text { longula }\end{array}$ & $\begin{array}{c}\text { Glomus } \\
\text { etunicatum }\end{array}$ \\
& $75 \mathrm{mM}^{*}$ & $50 \mathrm{mM}^{*}$ & $10 \mathrm{mM}^{*}$ \\
\hline Without storage & $63.14 \mathrm{a}$ & $23.24 \mathrm{a}$ & $11,36 \mathrm{~b}$ \\
$4^{\circ} \mathrm{C}$ & $61.82 \mathrm{a}$ & $18.81 \mathrm{ab}$ & $27.58 \mathrm{a}$ \\
$28^{\circ} \mathrm{C}$ & $63.35 \mathrm{a}$ & $7.31 \mathrm{~b}$ & $14.61 \mathrm{~b}$ \\
\hline
\end{tabular}

$* 75,50$ and $10 \mathrm{mM}=$ concentrations of Tris- $\mathrm{HCl}$ added to the nutrient solution. Means followed by the same letter (column) do not differ by the LSD test $(\mathrm{P}<0.05)$.

Species of Gigaspora were not successfully cultivated in aeroponic systems. The supply of nutrient solution with Tris$\mathrm{HCl}$ may constitute an alternative for large scale production of this fungus. Millner and Kitt (13) obtained high production of spores of G. margarita using $0.5 \mathrm{mM}$ of MES in the nutrient solution; in the same way, Silva et al. (17) observed high sporulation of G. margarita when adding $50 \mathrm{mM}$ of Tris- $\mathrm{HCl}$ to the nutrient solution.

There are recommendations for preservation of the inoculum in the conditions under which it was produced (11). However, for inoculum produced in tropical conditions, as in this work, the maintenance at $4^{\circ} \mathrm{C}$ was better for preserving the infective potential of the tested AMF, in comparison with storage at environmental temperature $\left(28^{\circ} \mathrm{C}\right)$. This can be due to the uniformity of germination (16), as well as to higher longevity of the structures at low temperatures, when metabolism is reduced. The results obtained agree with those that recommend maintenance of AMF inoculum at low temperatures (22). Juge et al. (10) mentioned that low temperatures can reduce the mortality of spores.

The only infective unit of Gigasporaceae is the spore (1), which is more resistant than the hypha (18). This may explain why spores of G. albida maintained its infectivity after storage. The percentage of colonization by A. longula was reduced after 120 days at room temperature, what could be explained by loss of hyphal viability as well as to the dormancy of the spores, a characteristic of the genus Acaulospora (2).

The inoculum of G. etunicatum maintained at $4^{\circ} \mathrm{C}$ produced higher mycorrhizal colonization than that stored at room temperature. Wagner et al. (24) observed increase in number of infective propagules of Glomus claroideum when stored at $4^{\circ} \mathrm{C}$ in comparison with maintenance at room temperature $\left(24^{\circ} \mathrm{C}\right)$. In this work, the increase on infectivity of G. etunicatum maintained at $4^{\circ} \mathrm{C}$ might be related to inactivation of inhibitors or activation of germination promoters as suggested by Louis and Lim (11).

Only G. albida and G. etunicatum attained the quality control patterns for production of commercial inoculum, forming at least $25 \%$ of mycorrhizal colonization (7). Production in large scale of inoculum of these isolates can be obtained by using the methods here described, which include addition of Tris- $\mathrm{HCl}$ buffer in the nutrient solution and storage at $4^{\circ} \mathrm{C}$.

\section{ACKNOWLEDGEMENTS}

Thanks are due to CAPES (Coordenação de Aperfeiçoamento de Pessoal de Nível Superior), for providing a PhD scholarship (Programa de Pós-Graduação em Biologia de Fungos) for the first author and to $\mathrm{CNPq}$ (Conselho Nacional de Desenvolvimento Científico e Tecnológico) for financial support. Special thanks to Dr. David Douds Jr. for suggestions in the content and corrections of the English text.

\section{RESUMO}

\section{Produção e infectividade de inóculo de fungos micorrízicos arbusculares multiplicados em substrato suplementado com tampão Tris-HCl}

O efeito da adição do tampão Tris-HCl na produção e infectividade de inóculo foi investigado. A esporulação de Glomus etunicatum, Acaulospora longula e Gigaspora albida foi incrementada utilizando solução com tampão. A infectividade de G. etunicatum aumentou após estocagem, sugerindo que o inóculo deste isolado é beneficiado pelo armazenamento.

Palavras-chave: esporulação, estocagem, micorriza, tampão orgânico

\section{REFERENCES}

1. Bierman, B.; Linderman, R.G. (1983). Use of vesicular-arbuscular mycorrhizal roots, intraradical vesicles and extraradical vesicles as inoculum. New Phytol., 95, 97-105.

2. Douds Jr, D.D.; Schenck, N.C. (1991). Germination and hyphal growth of VAM fungi during and after storage in soil at 5 matric potentials. Soil Biol. Biochem., 23, 177-183.

3. Douds Jr., D.D. (1997). A procedure for the establishment of Glomus mosseae in dual culture with Ri-T-DNA transformed carrot roots. Mycorrhiza, 7, 57-61.

4. Gerdemann, J.W.; Nicolson, T.H. (1963). Spores of mycorrhizal Endogone species extracted from soil by wet sieving and decanting. Trans. Br. Mycol. Soc., 46, 235-244.

5. Giovannetti, M.; Mosse, B. (1980). An evaluation of techniques for measuring vesicular arbuscular mycorrhizal infection in roots. New Phytol., 84, 489-500.

6. Hart, M.M.; Reader, R.J. (2002). Taxonomic basis for variation in the colonization strategy of arbuscular mycorrhizal fungi. New Phytol., 153, 335-344. 
7. INVAM. 2001. Available at: http://invam.caf.wvu.edu. Accessed Ago 2001

8. Jarstfer, A.G.; Sylvia, D.M. (1992). Inoculum production and inoculation strategies for vesicular arbuscular mycorrhizal fungi. In: Blaine Meeting Jr., F. (ed.), Soil Microbial Ecology. Application in Agricultural and Environmental Management. Marcel Decker, New York, p.349-369.

9. Jenkins, W.R. (1964). A rapid centrifugal-flotation technique for separating nematodes from soil. Pl. Dis. Rep., 48, 692.

10. Juge, C.; Samson, J.; Bastien, C.; Vierheilig, H.; Coughlan, A.; Piché, Y. (2002) Breaking dormancy in spores of the arbuscular mycorrhizal fungus Glomus intraradices: a critical cold-storage period. Mycorrhiza, $13,37-42$.

11. Louis, I.; Lim, G. (1988). Effect of storage inoculum on spore germination of a tropical isolate of Glomus clarum. Mycologia, 80, 157-161.

12. Masoro, E.J.; Siegel, P.D. (1979). Equilíbrio ácido básico. Interamericana, Rio de Janeiro.

13. Millner, P.D.; Kitt, D.G. (1992). The Beltsville method for soiless production of vesicular-arbuscular mycorrhizal fungi. Mycorrhiza, 2, 9-15.

14. Pawlowska, T.E.; Douds, D.D.; Charvat, I. (1999). In vitro propagation and life cycle of the arbuscular mycorrhizal fungus Glomus etunicatum. Mycol. Res., 103, 1549-1556.

15. Phillips, J.M.; Hayman, D.S. (1970). Improved procedures for clearing roots and staining parasitic and vesicular arbuscular mycorrhizal fungi for rapid assessment of infection. Trans. Br. Mycol. Soc., 55, 157-161.
16. Safir, G.R.; Coley, S.C.; Siqueira, J.O.; Carlson, P.S. (1990). Improvement and syncronization of VA mycorrhiza fungal spore germination by short-term cold storage. Soil Biol. Biochem., 22, 109-111.

17. Silva, F.S.B.; Yano-Melo, A.M.; Brandão, J.A.C.; Maia, L.C. (2005). Sporulation of arbuscular mycorrhizal fungi fungi using Tris-HCl buffer in addition to nutrient solutions. Braz. J. Microbiol., 36, 327-332.

18. Staddon, P.L.; Fitter, A.H. (2001). The differential vitality of intraradical mycorrhizal. Stasoft. (1997). Statistica for Windows. Tulsa, USA.

19. Sylvia, D.M. (1999). Fundamentals and applications of arbuscular mycorrhizae: A "biofertilizer" perspective. In: J.O. Siqueira, F.M.S Moreira, A.S. Lopes, L.R.G. Guilherme, V. Faquin, A.E. Furtini Neto, J.G. Carvalho (eds.). Inter-relação Fertilidade, Biologia de solo e Nutrição de plantas. SBCS, UFLA, DCS, Lavras, p.705-723.

20. Taiz, L.; Zeiger, E. (1998). Plant Physiology. Sinauer Associates Inc., Publishers, Sunderland, Massachusetts.

21. Talukdar, N.C; Germida, J.J. (2001). Propagation and storage of vesicular-arbuscular mycorrhizal fungi isolated from Saskatchewan agricultural soil. Can. J. Bot., 71, 1328-1335.

22. Tommerup, I.C. (1987). Physiology and ecology of VAM spore germination and dormancy in soil. Proceedings of the $7^{\text {th }}$ NACOM, Gainsville, Florida, p.175-177.

23. Wagner, S.C.; Skipper, H.D.; Walley, F.; Bridges, W.B. (2001). Longterm survival of Glomus claroideum propagules from soil pot cultures under simulated conditions. Mycologia, 93, 815-820. 